\title{
Antibacterial activity of lactic acid bacteria isolated from Dengke Naniura of Carp (Cyprinus carpio) against diarrhea-causing pathogenic bacteria
}

\author{
NASRI ${ }^{1}$, URIP HARAHAP ${ }^{2, \bullet}$, JANSEN SILALAHI ${ }^{3}$, DENNY SATRIA ${ }^{3}$ \\ ${ }^{1}$ Department of Pharmaceutical Biology, Faculty of Pharmacy, Universitas Sumatera Utara. Jl. Tri Dharma No. 5, Kampus USU, Medan 20155, \\ North Sumatra, Indonesia \\ ${ }^{2}$ Department of Pharmacology, Faculty of Pharmacy, Universitas Sumatera Utara. Jl. Tri Dharma No. 5, Kampus USU, Medan 20155, North \\ Sumatra, Indonesia \\ ${ }^{3}$ Department of Pharmaceutical Chemistry, Faculty of Pharmacy, Universitas Sumatera Utara. Jl. Tri Dharma No. 5, Kampus USU, Medan 20155, North \\ Sumatra, Indonesia.`email: urip@usu.ac.id
}

Manuscript received: 31 May 2021. Revision accepted: 5 July 2021.

\begin{abstract}
Nasri, Harahap U, Silalahi J, Satria D. 2021. Antibacterial activity of lactic acid bacteria isolated from Dengke Naniura of Carp (Cyprinus carpio) against diarrhea-causing pathogenic bacteria. Biodiversitas 22: 3098-3104. Diarrhea is the discharge of liquid or watery stools 3 to 4 times a day caused by a bacterial infection. Treatments for diarrhea are probiotics, which have a beneficial effect on the health of the host such as antibacterial. Traditional Batak Toba fermented food, Dengke Naniura, is a source of probiotics. This study aimed to determine the minimum inhibitory concentration, minimum bactericidal concentration, and leakage of DNA and protein from lactic acid bacteria against pathogens. Isolation of LAB was obtained from Dengke Naniura by pour plate method on deMann Rogosa and Sharpe Agar $+\mathrm{CaCO}_{3} 1 \%$. In this study, Characterization and analysis of bacterial sequencing used Polymerase Chain Reaction. Determination of MIC used the agar diffusion method. The MBC test used the streaking method which was a stroke from the inhibition zone formed. DNA and protein leakage was measured using spectrophotometry UV-VIS (260nm and 280nm). The isolation results obtained were Lactobacillus fermentum, the characterization showed that the bacteria were Gram-positive, bacilli, non-sporing, catalase-negative, and able to ferment sugar. The MIC determination was obtained at a concentration of $10 \% \mathrm{v} / \mathrm{v}$ with a clear zone diameter. Determination of MBC against pathogens was obtained at different concentrations. The results of DNA and protein leakage showed an increased absorption (260nm and 280nm).
\end{abstract}

Keyword: Antibacterial, Dengke Naniura, lactic acid bacteria, leakage of DNA and protein

\section{INTRODUCTION}

Diarrhea is a disease that often occurs among people, especially in developing countries. Acute diarrhea is the occurrence of liquid or watery feces 3 to 4 times a day. Bacterial etiology can be caused by non-infectious causes, but some bacteria can become infectious agents, such as Vibrio cholera, Enterotocxigenic Escherichia coli, Clostridium perfringens, Staphylococcus aureus, Bacillus cereus, Shigella, non-typhoidal Salmonella, Vibrio parahemolyticus, Clostridium difficile, and Campylobacter. Bacterial agents secrete toxins that act on the small intestine where the fluid is secreted into the lumen. It is also possible for mucosal damage, especially to the ileum and colon, due to ulcerative colitis (Tejan et al. 2018).

The prevalence of diarrhea in developing countries is reported annually to be around 2.5 billion cases of diarrhea in children under 5 years, of which there are as many as 1400 deaths (Sanyaolu et al. 2020). In some parts of the world, the mortality rate due to diarrhea is around $63 \%$, which is the second leading cause of death in infants in developing countries (Ugboko et al. 2020). Based on the results of the Riset Kesehatan Dasar report (RISKESDAS 2007) diarrhea is the leading cause of death in infants and children. A total of $31.4 \%$ mortality rate in infants (aged 0 -
12 months) and $25.2 \%$ mortality rate in children (aged 0-59 months) were due to diarrhea (Sari and Budyanra 2017).

Probiotics are microorganisms that can provide beneficial effects on human health. Several studies reported the effect of probiotics to prevent and reduce acute diarrhea, inflammation, hypertension, and diabetes (Manik et al. 2021). The traditional food of Batak Toba is Dengke Naniura which is served without cooking, only by fermentation using Jungga acid (Citrus jambhiri) with the addition of other spices (Hutahaean et al. 2019). Lactic acid bacteria are a source of probiotics that can be found in fermented foods such as Dengke Naniura. By turning common carp into Dengke Naniura with the addition of Jungga acid, it can kill and inhibit the growth of pathogenic bacteria that cannot survive in acidic $\mathrm{pH}$, while LAB works and survive in acidic pH (Haro et al. 2020). Research showed several Lactobacillus (lactic acid bacteria/LAB) antibacterial mechanisms such as competing for receptors, nutrients, and boosting immunity. LAB can produce organic compounds such as formic acid, lactic acid, acetic acid, and other acids that can lower the $\mathrm{pH}$ of the intestine. Another mechanism of LAB is secreted antimicrobial compounds such as ethanol, hydrogen peroxide, fatty acids, and bacteriocins (Chen et al. 2019). 
According to the background, this study aims to isolate the LAB from Dengke Naniura and analyze the antibacterial mechanism (MIC, MBC, DNA, and protein leakage) against diarrhea-causing pathogenic bacteria, Gram-positive (Staphylococcus aureus and Bacillus cereus), and Gram-negative (Escherichia coli and Salmonella typhi).

\section{MATERIALS AND METHODS}

\section{Materials and apparatus}

Diarrhea-causing pathogenic bacteria were Gramnegative (Escherichia coli ATCC 25922, and Salmonella typhi ATCC 19430) and Gram-positive (Bacillus cereus ATCC 14579 and Staphylococcus aureus ATCC 6538). Lactic acid bacteria isolated were obtained from Dengke Naniura. The medium used were deMann Rogosa and Sharpe Agar (MRSA), deMann Rogosa and Sharpe Broth (MRSB), Nutrient Broth (NB), Nutrient Agar (NA), Peptone Dilution Fluid (PDF), $\mathrm{CaCO}_{3}$, Triple Sugar Iron Agar (TSIA), Tryptic Soy Agar (TSA), Gram staining kit, $\mathrm{H}_{2} \mathrm{O}_{2} 3 \%$, phosphate buffer $\mathrm{pH} 7.0$, and Presto ${ }^{\mathrm{TM}}$ Mini gDNA Geneaid Biotech Ltd. The apparatus used were an incubator, microscope, vortex, centrifuge, Polymerase Chain Reaction (PCR), spectrophotometry UV-Visible, and glassware from the Microbiology Laboratory, Faculty of Pharmacy, Universitas Sumatera Utara. Medan, Indonesia.

\section{Isolation and characterization of lactic acid bacteria}

Isolation of LAB from Dengke Naniura was using the dilution method with MRSB medium. $25 \mathrm{~g}$ of Dengke Naniura was mixed with $225 \mathrm{~mL}$ of MRSB then homogenized and incubated at $37^{\circ} \mathrm{C}$ for $24-48$ hours. $1 \mathrm{~mL}$ of the incubated suspension was put into $9 \mathrm{~mL}$ PDF media and homogenized. A series of dilutions were carried out from $10^{-2}$ to $10^{-10}$. From $10^{-10}$ dilution $1 \mathrm{ml}$ pipettes and transferred into sterile Petri dishes then added $15 \mathrm{ml}$ of MRSA + $\mathrm{CaCO}_{3} 1 \% 15 \mathrm{ml}$, and incubated at $37^{\circ} \mathrm{C}$ for 24 48 hours. Isolation results showed a clear zone around the colony. Then it was taken using ose and cultured repeatedly 3-4 times to get pure bacterial colonies (Haro et al. 2020). LAB obtained were examined for bacterial morphology (color, shape, and size), Gram-staining of bacteria, catalase-test, fermentation type, gas formation, $\mathrm{H}_{2} \mathrm{~S}$, and TSIA test (Hutahaean et al. 2019).

\section{Extraction and amplification of DNA}

DNA extraction was carried out based on the procedure available in the extraction tool from Presto $^{\mathrm{TM}}$ Mini gDNA from Geneaid Biotech Ltd. The extracted DNA template was amplified with the $16 \mathrm{~S}$ rRNA gene with fD1_rP2 Reverse primer (5'-ACG GCT ACC TTG TTA CGA CTT3') and Forward (5'- GAG TTT GAT CCT GGC TCA-3') with a concentration of $1 \mathrm{nM} / \mu \mathrm{L}$. The $50 \mu \mathrm{L}$ PCR mixture contained $2 \mu \mathrm{L}$ of Primer R $(1 \mu \mathrm{M}), 2 \mu \mathrm{L}$ of Primer F $(1 \mu \mathrm{M})$, and $19 \mu \mathrm{L}$ of nuclease-free water. The process of denaturation, annealing, and elongation consists of 30 cycles. The stages of each cycle comprised of predenaturation at $94^{\circ} \mathrm{C}$ for 3 minutes, denaturation at $94^{\circ} \mathrm{C}$ for 30 seconds, annealing at $52^{\circ} \mathrm{C}$ for 1 minute, elongation at $72^{\circ} \mathrm{C}$ for 30 seconds, and finalization at $72^{\circ} \mathrm{C}$ for 5 minutes then sample temperature at $4^{\circ} \mathrm{C}$ for heat preservation. Amplification is performed on an automatic temperature cycler (Kawthar et al. 2018). The PCR product was followed by electrophoresis using $1 \%$ agarose (agarose gel was added with ethidium bromide). Electrophoresis was carried out at 80 volts for 60 minutes, then DNA visualization was performed using a UV transilluminator and documented with gel documentation (Fitri et al. 2017).

DNA base sequencing and identification of bacterial species

The PCR product was then purified and sequenced at the $1^{\text {st }}$ Base Laboratory, Singapore. Nucleotide sequences were aligned with GenBank data using the BLAST software from NCBI (National Center for Biotechnology Information) and Sequence Scanner Software 2 for DNA sequence consensus, where FASTA was compared against data in the most recent NCBI databases. Bacteria with homologs greater than $97 \%$ were selected as identified bacteria (Fitri et al. 2017).

\section{Determination of minimum inhibitory concentration}

MIC determination against pathogenic bacteria causing diarrhea was carried out by agar diffusion method (wells method) on MRSA and NA bilayer media. Suspension of $\mathrm{LAB}\left(10^{8} \mathrm{CFU} / \mathrm{mL}\right)$ with various concentrations $(5 \%, 10 \%$, $20 \%, 40 \%, 60 \%, 80 \%, 100 \%$ and Lacto B $100 \%, \% \mathrm{v} / \mathrm{v}$ ) of $50 \mu \mathrm{L}$ dropped on each well then left for 15 minutes and incubated at $35 \pm 2{ }^{\circ} \mathrm{C}$ for $18-24$ hours, repeated 3 times (Haro et al. 2020). In this study, $0.2 \%$ injection of ciprofloxacin antibiotic was used as a positive control and aquadest as a negative control. After incubation, the inhibition zone around the wells which showed clear zones was observed. The zone of inhibition was measured using a digital caliper in $\mathrm{mm}$. The activity index was calculated using the formula below: (Kuspradini et al. 2019)

Activity Index $=\frac{\text { inhibitor zone of LAB }}{\text { inhibitor zone of positive-control (antibiotic) }}$

\section{Determination of minimum bactericidal concentration}

MBC determination was taken from the clear zone of the MIC determination and subcultured onto Tryptic Soy Agar (TSA) media (Mostafa et al. 2018). It was incubated at $35 \pm 2^{\circ} \mathrm{C}$ for $18-24$ hours. The $\mathrm{MBC}$ value was determined by the lowest concentration which reduced $98 \%-99.9 \%$ viability of the initial bacterial population (negative-control) (Balouiri et al. 2016). The reduction percentage and log reduction can be calculated by the formula: (Ashakirin et al. 2017)

Percent reduction $=\frac{(B-A)}{B} x 100 \%$

Log Reduction $=\log (\mathrm{B}-\mathrm{A})$

Where:

A: number of bacterial colonies at each concentration

B: number of colonies in negative control (Yang et al., 2019). 


\section{Determination of leakage DNA and protein}

The suspension of the test pathogenic bacteria that had been grown for 24 hours in $10 \mathrm{~mL} \mathrm{NB}$ medium was taken and centrifuged at $3500 \mathrm{rpm}$ for 20 minutes. The supernatant was discarded then the pellets were washed with phosphate buffer $\mathrm{pH} 7.0$ for 2 times, then suspended in $10 \mathrm{~mL}$ phosphate buffer $\mathrm{pH}$ 7.0. Furthermore, the metabolites of lactic acid bacteria were added with a concentration of $1 / 2$ MIC, 1 MIC, 2 MIC, and 4 MIC. Subsequently, it was incubated with an incubator at a temperature of $35 \pm 2{ }^{\circ} \mathrm{C}$ for 24 hours. The suspension was centrifuged at $3500 \mathrm{rpm}$ for 20 minutes. Separate the supernatant with pellets. The absorbance of the supernatant was measured using a spectrophotometer UV-VIS at a wavelength of $260 \mathrm{~nm}$ and $280 \mathrm{~nm}$. The $260 \mathrm{~nm}$ wavelength is used to measure the nitrogen content of nucleic acids, while the $280 \mathrm{~nm}$ wavelength is used to measure the nitrogen content of cell proteins (Asriani et al., 2007).

\section{Statistical analysis}

Each test was carried out in three repetitions and the values were presented as mean and standard deviation. The statistical analysis software used was SPSS v.22. Data were analyzed using variance (ANOVA) analysis followed by Post Hoc LSD test when required with a level of significance of $p<0.05$.

\section{RESULTS AND DISCUSSION}

\section{Isolation and characterization of lactic acid bacteria}

Isolation of LAB from Dengke Naniura was using selective media deMann Rogosa and Sharpe Agar $+\mathrm{CaCO}_{3}$ 1\%. 1 lactic acid bacteria isolate was obtained which was marked by the presence of a clear zone around the colony after 24-48 hours incubation. The characterization of LAB can be seen in Table 1.

The characterization of LAB showed oval colony shape, rounded-edge shape, flat surface height, and white colony color. With Gram stain, it was seen that Grampositive bacteria were characterized by purple bacteria and the shape of bacilli cells. Catalase-test by dropping 3 drops of $\mathrm{H}_{2} \mathrm{O}_{2} 3 \%$ did not show the formation of gas bubbles. Tests using TSIA media showed that lactic acid bacteria were able to ferment the sugars contained in TSIA media (lactose, sucrose, and dextrose) characterized by a change in the color of the media to yellow. LAB did not produce $\mathrm{H}_{2} \mathrm{~S}$. Furthermore, the type of fermentation shows homofermentative because the test using the Durham tube LAB did not show any gas bubbles.

\section{DNA extraction and amplification}

The extracted DNA was amplified using a thermal cycler and tested for quantity and quality of DNA by electrophoresis and nano spectrophotometer (DNA concentration $5.720 \mathrm{ng} / \mu \mathrm{L}$ with $\mathrm{A} 260 / 280$ value is 2.014). From the electrophoresis results, the best amplification optimization was obtained at an aneling temperature of $52^{\circ} \mathrm{C}$ by showing a very clear band at $1500 \mathrm{bp}$ which can be seen in Figure 1, where this band indicated the amplicon of bacteria (Klindworth et al. 2013).

DNA base sequencing and identification of bacteria species

The results of $99 \%$ identical bacterial DNA sequencing were derived from Lactobacillus fermentum bacteria with DNA sequences and the results of homologous database adjustments can be seen in Table 2 .

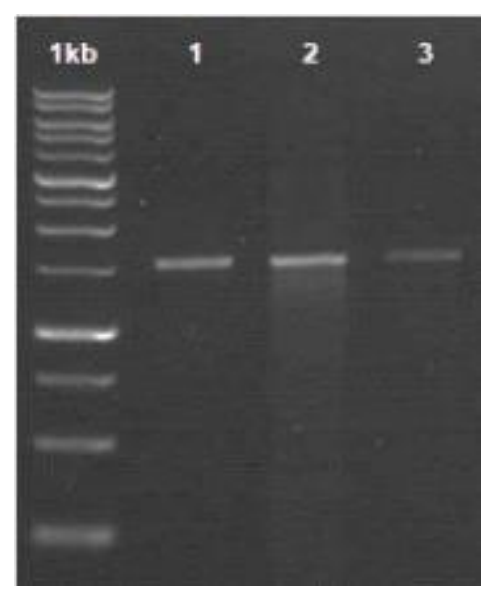

Figure 1. Electrophoresis results from DNA amplification. Note: *aneling optimization of amplification: 1 . Temperature $50^{\circ} \mathrm{C} ; 2$. Temperature $52^{\circ} \mathrm{C} ; 3$. Temperature $54^{\circ} \mathrm{C}$

Table 1. Characteristics of LAB isolated from Dengke Naniura

\begin{tabular}{ll} 
Characteristics & Isolate LAB \\
\hline Colony forms & Oval \\
Edge shape & Round \\
The height of the surface & Flat \\
Colony color & White \\
Gram stain & Gram + \\
Bacterial cell shape & Basil \\
Catalase-test & Negative \\
TSIA & Positive \\
Gas & Negative \\
$\mathrm{H}_{2} \mathrm{~S}$ & Negative \\
Fermentation Type & Homofermentative \\
\hline
\end{tabular}

Table 2. NCBI database homologs of DNA sequences

\begin{tabular}{|c|c|c|c|c|c|c|}
\hline Description & $\begin{array}{l}\text { Max } \\
\text { score }\end{array}$ & $\begin{array}{l}\text { Total } \\
\text { score }\end{array}$ & $\begin{array}{l}\text { Query } \\
\text { cover }\end{array}$ & E value & ID & Accession \\
\hline Lactobacillus fermentum strain LF 16S Ribosomal RNA gene, partial sequence & 2625 & 2625 & $100 \%$ & 0.0 & $99 \%$ & MK245999.1 \\
\hline Lactobacillus fermentum strain LMEM36 16S Ribosomal RNA gene & 2625 & 2625 & $100 \%$ & 0.0 & $99 \%$ & MK239985.1 \\
\hline Lactobacillus fermentum strain LMEM19 16S Ribosomal RNA gene & 2526 & 2625 & $100 \%$ & 0.0 & $99 \%$ & MK239955.1 \\
\hline
\end{tabular}


DNA sequence:

TTGATTGATGGTGCTTGCACCTGATTGATTTTGGTTGCCAACGAGTGGCGGACGGGTGAGTAACACGTAGGTAACCTGC

CCAGAAGCGGGGGACAACATTTGGAAACAGATGCTAATACCGCATAACAACGTTGTTCGCATGAACAACGCTTAAAAGATGG СTTCTCGCTATCACTTCTGGATGGACCTGCGGTGCATTAGCTTGTTGGTGGGGTAACGGCCTACCAAGGCGATGATGCATAG CCGAGTTGAGAGACTGATCGGCCACAATGGGACTGAGACACGGCCCATACTCCTACGGGAGGCAGCAGTAGGGAATCTTCCA CAATGGGCGCAAGCCTGATGGAGCAACACCGCGTGAGTGAAGAAGGGTTTCGGCTCGTAAAGCTCTGTTGTTAAAGAAGAAC ACGTATGAGAGTAACTGTTCATACGTTGACGGTATTTAACCAGAAAGTCACGGCTAACTACGTGCCAGCAGCCGCGGTAATA CGTAGGTGGCAAGCGTTATCCGGATTTATTGGGCGTAAAGAGAGTGCAGGCGGTTTTCTAAGTCTGATGTGAAAGCCTTCGG CTTAACCGGAGAAGTGCATCGGAAACTGGATAACTTGAGTGCAGAAGAGGGTAGTGGAACTCCATGTGTAGCGGTGGAATGC GTAGATATATGGAAGAACACCAGTGGCGAAGGCGGCTACCTGGTCTGCAACTGACGCTGAGACTCGAAAGCATGGGTAGCGA ACAGGATTAGATACCCTGGTAGTCCATGCCGTAAACGATGAGTGCTAGGTGTTGGAGGGTTTCCGCCCTTCAGTGCCGGAGC TAACGCATTAAGCACTCCGCCTGGGGAGTACGACCGCAAGGTTGAAACTCAAAGGAATTGACGGGGGCCCGCACAAGCGGTG GARCATGTGGTTTAATTCGAAGCTACGCGAAGAACCTTACCAGGTCTTGACATCTTGCGCCAACCCTAGAGATAGGGCGTTT CCTTCGGGAACGCAATGACAGGTGGTGCATGGTCGTCGTCAGCTCGTGTCGTGAGATGTTGGGTTAAGTCCCGCAACGAGCG CAACCCTTGTTACTAGTTGCCAGCATTAAGTTGGGCACTCTAGTGAGACTGCCGGTGACAAACCGGAGGAAGGTGGGGACGA CGTCAGATCATCATGCCCCTTATGACCTGGGCTACACACGTGCTACAATGGACGGTACAACGAGTCGCGAACTCGCGAGGGC AAGCAAATCTCTTAAAACCGTTCTCAGTTCGGACTGCAGGCTGCAACTCGCCTGCACGAAGTCGGAATCGCTAGTAATCGCG GATCAGCATGCCGCGGTGAATACGTTCCCGGGCCTTGTACACACCGCCCGTCACACCATGAGAGTTTGTAACACCCAAAGTC GGTGGGGTAACCTTTTAGGAGCCAGCCGCCTAAGGATCATGCCCCTTATGACCTGGGCTACACACGTGCTACAATGGACGGT ACAACGAGTCGCGAACTCGCGAGGGCAAGCAAATCTCTTAAAACCGTTCTCAGTTCGGACTGCAGGCTGCAACTCGCCTGCA CGAAGTCGGAATCGCTAGTAATCGCGGATCAGCATGCCGCGGTGAATACGTTCCCGGGCCTTGTACACACCGCCCGTCACAC CATGAGAGTTTGTAACACCCAAAGTCGGTGGGGTAACCTTTTAGGAGCCAGCCGCCTAAGGATCATGCCCCTTATGACCTGG GCTACACACGTGCTACAATGGACGGTACAACGAGTCGCGAACTCGCGAGGGCAAGCAAATCTCTTAAAACCGTTCTCAGTTC GGACTGCAGGCTGCAACTCGCCTGCACGAAGTCGGAATCGCTAGTAATCGCGGATCAGCATGCCGCGGTGAATACGTTCCCG GGCCTTGTACACACCGCCCGTCACACCATGAGAGTTTGTAACACCCAAAGTCGGTGGGGTAACCTTTTAGGAGCCAGCCGCC TAAGG

Determination of minimum inhibitory concentration

Determination of MIC against the bacteria $S$. aureus, $B$. cereus, E. coli, and S. typhi were obtained at $10 \% \mathrm{v} / \mathrm{v}$ concentration with a clear zone diameter of each $9.13 \pm$ $0.51 \mathrm{~mm}, 7.87 \pm 0.15 \mathrm{~mm}, 7.27 \pm 0.25 \mathrm{~mm}$, and $7.13 \pm$ $0.15 \mathrm{~mm}$. The activity index value of each bacteria at $100 \%$ concentration were $0.51 \pm 0.06$ ( $S$. aureus $), 0.54 \pm 0.86$ (B. cereus), $0.54 \pm 0.04$ (E. coli), and $0.56 \pm 0.14$ (S. typhi). The diameter of the inhibition zone for each bacterium can be seen in Table 3. (sig. 0.000; statistically there was a significant difference between means at $\mathrm{p}<0.05$ ).

Determination of minimum bactericidal concentration

Determination of MBC against pathogens showed that $S$. aureus at a concentration of $40 \% \mathrm{v} / \mathrm{v}$ with a $98.3 \%$ reduction percent, B. cereus at a concentration of $80 \% \mathrm{v} / \mathrm{v}$ with a $98.0 \%$ reduction percent, $E$. coli at a concentration of $80.0 \% \mathrm{v} / \mathrm{v}$ with a $99.0 \%$ reduction percent, and $S$. typhi at a concentration of $100.0 \% \mathrm{v} / \mathrm{v}$ with a $99.0 \%$ reduction percent. The results of the MBC percentage values can be seen in Table 4. Figure 2 shows that the log reduction graph of the percent reduction indicates that a high percent reduction also influences a high $\log$ reduction. The $\log$ reduction value for $100 \% \mathrm{v}$ on $S$. aureus is $2.287, B$. cereus is $2.037, E$. coli is 2.088 , and $S$. typhi is 2.039 . This is because the number of bacterial colonies at each concentration showed a significantly different reduction with the number of colonies in the negative control. The percent reduction and $\log$ reduction values can be seen in Table 4.
Leakage of DNA and protein

The DNA and Protein leakage test results showed the absorbance of the bacterial cell supernatant at a wavelength of $260 \mathrm{~nm}$ and $280 \mathrm{~nm}$ which indicated an increase in the compound released by bacterial cells, which can be seen in Figures 3.A-3.D. LSD post hoc results showed sig. 0.000 in the negative control for all concentrations, sig. 0.012 at a concentration of $1 / 2 \mathrm{MIC}$ to $1 \mathrm{MIC}$, sig. 0.005 at a concentration of $1 \mathrm{MIC}$ to $2 \mathrm{MIC}$. It means that there is a significant difference between the negative control with each concentration and the difference between each concentration $(p<0.05)$. It can be seen in Figure 3 that the ratio of 260/280 $\mathrm{nm}$ of each compound released by bacterial cells increased. (sig. 0.000; statistically there was a significant difference between the means at $\mathrm{p}<0.05$ ).

\section{Discussion}

Bacteria isolated from Dengke Naniura produced 1 white oval-shaped bacterial colony and provided a clear zone around the bacteria. Because when MRSA $+\mathrm{CaCO}_{3}$ $1 \%$ media reacting with lactic acid which was metabolized from lactic acid bacteria, it will form calcium lactate which dissolves in the media and produces a clear zone around the bacterial colony (Haro et al. 2020) The characteristics of the LAB are similar to those of the Lactobacillus sp, namely purple Gram-positive bacteria, bacilli-shaped, nonspore, non-motile, catalase-negative, and able to ferment sugar (Hutahaean et al. 2019; Ismail et al. 2017; Manik et al. 2021). 
Table 3. The diameter of the zone of MIC of LAB against S. aureus, B. cereus, E. coli, and S. typhi

\begin{tabular}{|c|c|c|c|c|c|c|c|c|}
\hline \multirow{2}{*}{ Conc. $(\% \mathrm{v} / \mathrm{v})$} & \multicolumn{2}{|c|}{ S. aureus } & \multicolumn{2}{|c|}{ B. cereus } & \multicolumn{2}{|c|}{ E. coli } & \multicolumn{2}{|c|}{ S. typhi } \\
\hline & IZ & AI & IZ & AI & IZ & AI & IZ & AI \\
\hline - Control & $6.00 \pm 0.0$ & $0.17 \pm 0.00$ & $6.00 \pm 0.00^{\mathrm{b}}$ & $0.17 \pm 0.00$ & $6.00 \pm 0.00^{b}$ & $0.18 \pm 0.00$ & $6.00 \pm 0.00^{b}$ & $0.19 \pm 0.00$ \\
\hline $5 \%$ & & $17 \pm 0$ & $6.00 \pm 0.00^{\mathrm{bc}}$ & .00 & $6.00 \pm 0.00^{\mathrm{bc}}$ & & $6.00 \pm 0.00^{\mathrm{bc}}$ & \\
\hline $10 \%$ & & $0.27 \pm 0.34$ & $7.87 \pm 0.15^{\mathrm{ab}}$ & & & & & \\
\hline & $57 \pm 0.25^{\mathrm{ab}}$ & $0.34 \pm 0$ & 1 & $0.29 \pm$ & $9.43 \pm 0.32^{\mathrm{ab}}$ & & $8.47 \pm 0.25^{\mathrm{ab}}$ & \\
\hline & $.03 \pm 0.15^{\mathrm{ab}}$ & $0.41 \pm 0$ & $1407+04$ & $0.41 \pm 0$ & $14.20 \pm 0.53^{\mathrm{ab}}$ & & $12.93 \pm 0.21^{\mathrm{ab}}$ & \\
\hline & & $0.46=$ & $16.10 \pm 0.1$ & & $.17 \pm 0.25^{\mathrm{ab}}$ & & $\pm 0.40^{\mathrm{ab}}$ & \\
\hline & & & $1742+07$ & & $15.93 \pm 0.25^{\mathrm{ab}}$ & & $15.77 \pm 0.35^{\mathrm{ab}}$ & \\
\hline & & & & & & & $3 \pm 0.49^{a b}$ & \\
\hline & b & & $19.30 \pm 0$. & & $18.40 \pm$ & & $5^{\mathrm{ab}}$ & \\
\hline+ Control $*$ & $33.67 \pm 0.15^{\mathrm{a}}$ & $1.00 \pm 0.10$ & $33.77 \pm 0.12^{\mathrm{a}}$ & $1.00 \pm 0.10$ & $32.60 \pm 0.26^{\mathrm{ab}}$ & $1.00 \pm 0.10$ & $30.43 \pm 0.35^{\mathrm{ab}}$ & $1.00 \pm 0.10$ \\
\hline
\end{tabular}

Note: * Ciprofloxacin injection $0.2 \%$ was used as positive control; IZ: Inhibitor Zone; AI: Activity Index. Post Hoc LSD test that shows: ${ }^{a}$ Sig $(\mathrm{P})<0.05$ there was a significant difference with the negative control (sig. 0.000). ${ }^{\mathrm{b}} \mathrm{Sig}(\mathrm{P})<0.05$ there was a significant difference with the positive control (sig. 0.000). ${ }^{\mathrm{c}} \mathrm{Sig}(\mathrm{P})>0.05$ there was no significant difference with the negative control (sig. 1.000)

Table 4. The MBC of LAB against S. aureus, B. cereus, E. coli, and S. typhi

\begin{tabular}{|c|c|c|c|c|c|c|c|c|}
\hline \multirow[b]{2}{*}{$\begin{array}{l}\text { Conc. } \\
(\% \mathrm{v} / \mathrm{v})\end{array}$} & \multicolumn{2}{|c|}{ S. aureus } & \multicolumn{2}{|c|}{ B. cereus } & \multicolumn{2}{|c|}{ E. coli } & \multicolumn{2}{|c|}{ S. typhi } \\
\hline & $\begin{array}{c}\% \\
\text { Reduction }\end{array}$ & Log Reduction & $\begin{array}{c}\% \\
\text { Reduction }\end{array}$ & $\begin{array}{c}\text { Log } \\
\text { Reduction }\end{array}$ & $\begin{array}{c}\% \\
\text { Reduction }\end{array}$ & $\begin{array}{c}\text { Log } \\
\text { Reduction }\end{array}$ & $\begin{array}{c}\% \\
\text { Reduction }\end{array}$ & $\begin{array}{c}\text { Log } \\
\text { Reduction }\end{array}$ \\
\hline - Control & $0.0 \%$ & 0,000 & $0.0 \%$ & 0,000 & $0.0 \%$ & 0,000 & $0.0 \%$ & 0,000 \\
\hline $5 \%$ & $18.1 \%$ & 0.087 & $17.6 \%$ & 0.084 & $57.4 \%$ & 0.370 & $4.7 \%$ & 0.021 \\
\hline $10 \%$ & $25.8 \%$ & 0.130 & $21.3 \%$ & 0.104 & $66.3 \%$ & 0.473 & $23.6 \%$ & 0.117 \\
\hline $20 \%$ & $97.2 \%$ & 1,560 & $95.7 \%$ & 1,369 & $70.8 \%$ & 0.534 & $92.7 \%$ & 1,134 \\
\hline $40 \%$ & $98.3 \%$ & 1,780 & $97.0 \%$ & 1,518 & $96.0 \%$ & 1,403 & $93.2 \%$ & 1,169 \\
\hline $60 \%$ & $99.1 \%$ & 2,037 & $97.5 \%$ & 1,608 & $97.0 \%$ & 1,521 & $94.1 \%$ & 1,231 \\
\hline $80 \%$ & $99.4 \%$ & 2,241 & $98.0 \%$ & 1,698 & $99.0 \%$ & 1,998 & $94.5 \%$ & 1,264 \\
\hline $100 \%$ & $99.5 \%$ & 2,287 & $99.1 \%$ & 2,037 & $99.2 \%$ & 2,088 & $99.0 \%$ & 2,039 \\
\hline Lacto B & $99.8 \%$ & 2,639 & $99.3 \%$ & 2,127 & $99.2 \%$ & 2,124 & $99.4 \%$ & 2,257 \\
\hline+ Control $*$ & $100.0 \%$ & 4,258 & $99.7 \%$ & 2,464 & $99.4 \%$ & 2,248 & $99.8 \%$ & 2,671 \\
\hline
\end{tabular}

Note: * Ciprofloxacin injection $0.2 \%$ was used as a positive control

The extracted DNA after amplification and electrophoresis showed a clear band appearance at $1500 \mathrm{bp}$. Where this band indicates the amplicon of the bacteria (Klindworth et al. 2013). Sequencing of amplified DNA obtained $99 \%$ identical bacterial DNA, which is a bacterial derivative of Lactobacillus fermentum. Several similar studies also obtained the same results from the isolation of traditional foods from various countries. The fermentation process with fast acidification will produce more L.fermentum derivatives than the slow acidification process. Rapid acidification techniques are also needed to reduce fermentation time, spoilage contamination, and/or pathogenic microorganisms (Owusu-Kwarteng et al. 2015).

The antibacterial activity of $L$. fermentum isolates from Dengke Naniura showed antibacterial activity against the four bacteria that cause diarrhea, marked by the formation of a clear zone around the well which was given $L$. fermentum inoculum with various concentrations. Although the resulting inhibition zone is lower than the inhibition zone for positive control, it does not mean that the tested sample does not have antibacterial activity (Kuspradini et al. 2019). The MIC in S. aureus has an inhibition zone diameter of $9.13 \pm 0.51 \mathrm{~mm}$, in $B$. cereus the inhibition zone diameter is $7.87 \pm 0.15 \mathrm{~mm}$, in $E$. coli the inhibition zone diameter is $7.27 \pm 0.25 \mathrm{~mm}$, and in $S$. typhi the inhibition zone diameter is $7.13 \pm 0.15 \mathrm{~mm}$. Complete results can be seen in Table 3 .

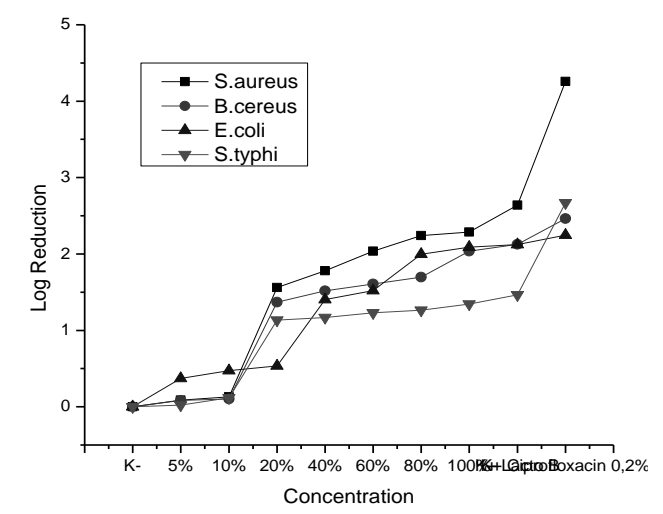

Figure 2. The log graph of the reduction of each concentration for each bacteria 


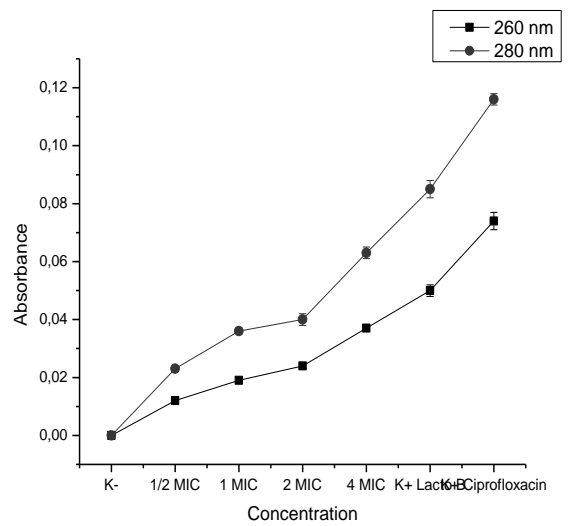

A. Staphylococcus aureus

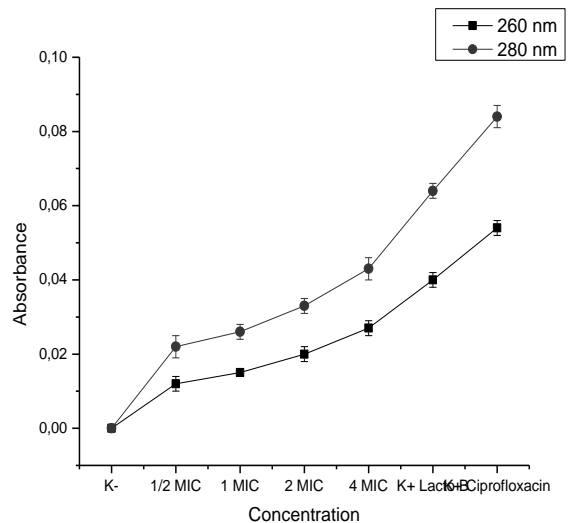

B. Bacillus cereus

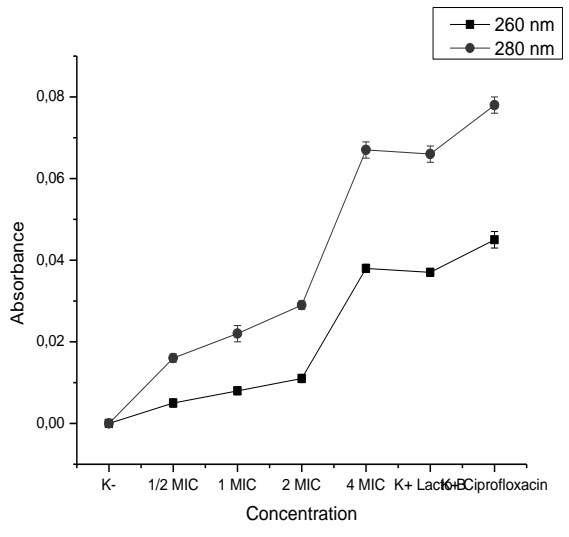

C. Escherichia coli

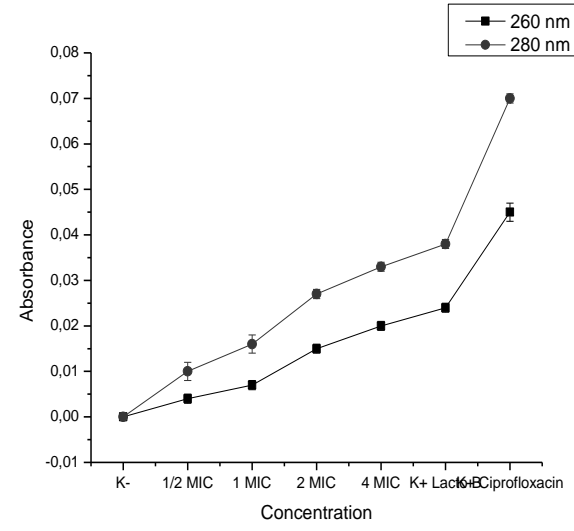

D. Salmonella typhi

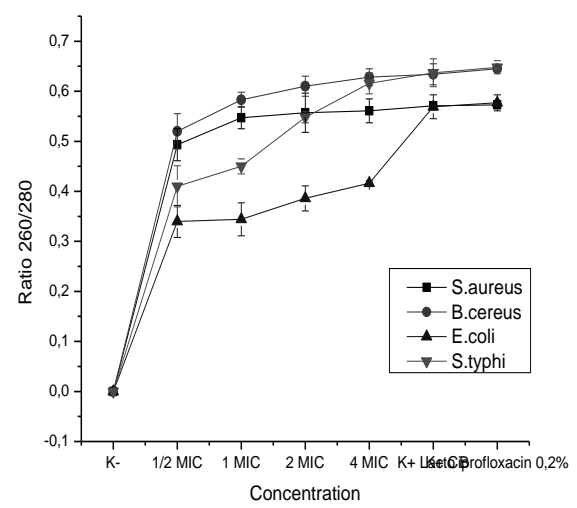

E. Ratio $260 / 280$

Figure 3. Leakage of DNA and protein in diarrhea-causing pathogenic bacteria cells that are given the antibacterial compound metabolite Lactobacillus fermentum

Davis and Stout (1971) Classification of the zone of inhibition (ZOI) is divided into 4 classifications according to the ZOI diameter, ZOI $>20 \mathrm{~mm}$ (very strong), $10-20 \mathrm{~mm}$ (strong), 5-10 mm (moderate), and $<5 \mathrm{~mm}$ (no response). The inhibition zone obtained different results depending on the metabolite compounds produced by the test isolate and the response of pathogenic bacteria to it (Ouchari et al. 2019). The activity index measurement aims to determine whether the antibacterial activity produced from the potential sample is comparable to the positive control (antibiotics). If the index activity value is equal to 1.00 then the activity is the same as the positive control activity (Kuspradini et al. 2019). The sample activity index at the highest concentration of $100 \%$ each has a value of $0.51 \pm$ 0.06 (S. aureus), $0.54 \pm 0.86$ (B. cereus), $0.54 \pm 0.04$ ( $E$. coli), and $0.56 \pm 0.14$ (S. typhi). From the results obtained, it can be considered that the L. fermentum has half the positive control potential (antibiotics).

The MBC determination was determined by streaking from each zone of inhibition resulting from the MIC test. From the test results, it was found that the MBC test sample for each bacteria was at different concentrations, 40\% $\%$ v (S. aureus: $98.3 \%), 80 \% \mathrm{v} / \mathrm{v}$ (B. cereus: $98.0 \%)$, $80 \% \mathrm{v} / \mathrm{v}$ (E. coli: $99.0 \%$ ) and $100 \% \mathrm{v} / \mathrm{v}$ (S. typhi: $99.0 \%)$. The determination of $\mathrm{MBC}$ is known to be the lowest concentration of antimicrobial agent needed to kill $98,0 \%$ $99.9 \%$ of the final colony number compared to the initial colony number (Balouiri et al. 2016).

Determination of bacterial cells leakage (wall/membrane) was analyzed by measuring the supernatant at a wavelength of 260 (nucleic acid) and 280 (protein) (Mierza et al. 2020). DNA and protein leakage is characterized by an increase in the absorbance of the cell supernatant measured at a wavelength of $260 \mathrm{~nm}$ and $280 \mathrm{~nm}$ (Asriani et al. 2007). The increase in absorbance which can be seen in Figure 3.A-3.D shows the release of metabolite compounds in bacterial cells, which can be in the form of RNA and its derivatives such as nucleotides which are absorbed in a wavelength of $260 \mathrm{~nm}$ and protein compounds at a wavelength of $280 \mathrm{~nm}$ ( $\mathrm{Lin}$ et al. 2000). Based on previous research, the addition of Artemisia asiatica essential oil to bacterial cultures, there was a shrinkage of bacteria and an increased release of constituents (Huang et al. 2018).

This research concludes that Lactobacillus fermentum isolated from Dengke Naniura has a potent antibacterial activity of MIC, MBC, DNA, and protein leakage. 


\section{ACKNOWLEDGEMENTS}

The authors wish to thank Microbiology Laboratory, Faculty of Pharmacy, Universitas Sumatera Utara for their support in this research.

\section{REFERENCE}

Ashakirin SN, Tripathy M, Patil UK. 2017. Antimicrobial activity of essential oils: exploration on mechanism of bioactivity. Intl J Pharm Sci Res 8 (8): 3187-3193. DOI: 10.13040/IJPSR.09758232.8(8).3187-93

Asriani, Laksmi BS, Yasni S. 2007. Mekanisme antibakteri metabolit Lb. plantarum kik dan monoasilgliserol minyak kelapa terhadap bakteri patogen pangan. In Jurnal Teknologi dan Industri Pangan 18 (2): 126132. [Indonesian]

Balouiri M, Sadiki M, Ibnsouda SK. 2016. Methods for in vitro evaluating antimicrobial activity: A review. J Pharm Anal 6 (2): 71-79. DOI: 10.1016/j.jpha.2015.11.005

Chen CC, Lai CC, Huang HL, Huang WY, Toh HS, Weng TC, Chuang YC, Lu YC, Tang HJ. 2019. Antimicrobial activity of Lactobacillus species against carbapenem-resistant Enterobacteriaceae. Front Microbiol 10 (APR): 1-10. DOI: 10.3389/fmicb.2019.00789

Davis WW, Stout TR. 1971. Disc plate method of microbiological antibiotic assay. II. Novel procedure offering improved accuracy. Appl Microbiol 22 (4): 666-670. DOI: 10.1128/aem.22.4.666670.1971.

Fitri DS, Pangastuti A, Susilowati AR, Sutarno S. 2017. Endophytic bacteria producing antibacterial against methicillin-resistant Staphylococcus aureus (MRSA) in seagrass from Rote Ndao, East Nusa Tenggara, Indonesia. Biodiversitas 18 (2): 733-740. DOI: $10.13057 /$ biodiv/d180242.

Haro G, Iksen I, Nasri N. 2020. Identification, characterization and antibacterial potential of probiotic lactic acid bacteria isolated from naniura (A traditional Batak fermented food from carp) against Salmonella typhi. Rasayan J Chem 13 (1): 464-468. DOI: 10.31788/RJC.2020.1315530.

Huang J, Qian C, Xu H, Huang Y. 2018. Antibacterial activity of Artemisia asiatica essential oil against some common respiratory infection causing bacterial strains and its mechanism of action in Haemophilus influenzae. Microb Pathog 114 (January): 470-475. DOI: 10.1016/j.micpath.2017.12.032.

Hutahaean AJ, Silalahi J, Suryanto D, Satria D. 2019. Characterisation of lactic acid bacteria from Dengke Naniura of common carp (Cyprinus carpio) with $\alpha$-glucosidase inhibitory activity. Open Access $\begin{array}{llll}\text { Macedonian J Med Sci } 7 \text { (22): 3794-3798. DOI: } & \end{array}$ 10.3889/oamjms.2019.506.

Ismail YS, Yulvizar C, Putriani. 2017. Isolasi, karakterisasi dan uji aktivitas antimikroba bakteri asam laktat dari fermentasi biji kakao (Theobroma cacao L.). Jurnal Bioleuser 1 (2): 45-53. [Indonesian]

Kawthar MA, Hanan BE, Yousif FHE. 2018. Molecular characterization of lactic acid bacteria isolated from starter dough of Sudanese sorghum fermented flatbread (Kissra). Pak J Nutr 17 (2): 57-63. DOI: 10.3923/pjn.2018.57.63

Klindworth A, Pruesse E, Schweer T, Peplies J, Quast C, Horn M, Glöckner FO. 2013. Evaluation of general 16S ribosomal RNA gene PCR primers for classical and next-generation sequencing-based diversity studies. Nucleic Acids Res 41 (1): 1-11. DOI: 10.1093/nar/gks808.

Kuspradini H, Putri AS, Egra S, Yanti Y. 2019. Short communication: In vitro antibacterial activity of essential oils from twelve aromatic plants from East Kalimantan, Indonesia. Biodiversitas 20 (7): 20392042. DOI: 10.13057/biodiv/d200733.

Lin CM, Preston JF, Wei CI. 2000. Antibacterial mechanism of allyl isothiocyanate. J Food Prot 63 (6): 727-734. DOI: 10.4315/0362028X-63.6.727.

Manik M, Kaban J, Silalahi J, Ginting M. 2021. Lactic acid bacteria (LAB) with probiotic potential from Dengke Naniura. Baghdad Sci J 18 (1): 35-40. DOI: 10.21123/bsj.2021.18.1.0035.

Mierza V, Rosidah, Haro G. 2020. Antibacterial activity and mechanism of action of rarugadong (Dioscorea pyrifolia Kunth.) tuber extracts on Escherichia coli and Staphylococcus aureus cell leakage. Rasayan J Chem 13 (3): 1894-1903. DOI: 10.31788/RJC.2020.1335864.

Mostafa AA, Al-Askar AA, Almaary KS, Dawoud TM, Sholkamy EN, Bakri MM. 2018. Antimicrobial activity of some plant extracts against bacterial strains causing food poisoning diseases. Saudi J Biol Sci 25 (2): 361-366. DOI: 10.1016/j.sjbs.2017.02.004.

Ouchari L, Boukeskasse A, Bouizgarne B, Ouhdouch Y. 2019. Antimicrobial potential of actinomycetes isolated from the unexplored hot Merzouga desert and their taxonomic diversity. Biol Open 8 (2). DOI: 10.1242/bio.035410.

Owusu-Kwarteng J, Tano-Debrah K, Akabanda F, Jespersen L. 2015. Technological properties and probiotic potential of Lactobacillus fermentum strain isolated from West African fermented millet dough Applied microbiology. BMC Microbiol 15 (1): 1-10. DOI: 10.1186/s12866-015-0602-6.

RISKESDAS. 2007. Laporan Nasional Riset Kesehatan Dasar. Badan Penelitian Dan Pengembangan Kesehatan, Jakarta. [Indonesian]

Sanyaolu A, Okorie C, Marinkovic A, Jaferi U, Prakash S. 2020. Global epidemiology and management of acute diarrhea in children from developing countries. Ann Pediatr Child Health 8 (8): 1205.

Sari DP, Budyanra B. 2017. The risk factor that affects children diarrhea in the Island of Java 2013 (Riskesdas 2013 data analysis). J Educational Health Commun Psychol 6 (1): 1. DOI: 10.12928/jehcp.v6i1.6615.

Tejan N, Datta P, Gupta V. 2018. Bacterial Diarrhoea: a Comprehensive Review. Intl J Pharm Sci Res 9 (12): 5015-5031. DOI: 10.13040/IJPSR.0975-8232.9(12).5015-31.

Ugboko HU, Nwinyi OC, Oranusi SU, Oyewale JO. 2020. Childhood diarrhoeal diseases in developing countries. Heliyon 6 (4): e03690. DOI: 10.1016/j.heliyon.2020.e03690.

Yang JH, Wu UI, Tai HM, Sheng WH. 2019. Effectiveness of an ultraviolet-C disinfection system for reduction of healthcareassociated pathogens. J Microbiol Immunol Infect 52 (3): 487-493. DOI: 10.1016/j.jmii.2017.08.017. 